\title{
Somatic Mutation of Human Immunoglobulin V Genes in the X-Linked HyperlgM Syndrome
}

\author{
Yu-Waye Chu, Elides Marin, Ramsay Fuleihan, ${ }^{*}$ Narayanaswamy Ramesh, * Fred S. Rosen, ${ }^{*}$ Raif S. Geha, * \\ and Richard A. Insel \\ Department of Pediatrics, Microbiology, and Immunology, University of Rochester School of Medicine and Dentistry, Rochester, \\ New York 14642; and *Harvard Medical School, Department of Pediatrics, Boston, Massachusetts 02138
}

\begin{abstract}
Somatic mutation of Ig variable regions occurs prominently in germinal centers, but it has been debated whether the mutation process initiates in germinal centers or is activated before germinal center entry of $B$ cells. We have analyzed for the presence of somatic mutation in Ig gene rearrangements of the nonpolymorphic human $V_{\mathrm{H} 6}$ gene in the $\mathrm{X}$-linked HyperIgM syndrome, which is associated with defective CD40 ligand expression and absence of germinal centers and generation of memory B lymphocytes. IgM and rare IgG $V_{\mathrm{H}}$ productive rearrangements were isolated from PBL of patients with $\mathrm{X}$-linked HyperIgM syndrome. Although the majority of both the IgM and IgG $V_{\mathrm{H} 6}$ rearrangements had a germline $V_{\mathrm{H} 6}$ sequence, 7 of $102 V_{\mathrm{H} 6}$ IgM and 1 of 6 IgG rearrangements had a mutated $V_{H 6}$ gene. The mutation frequency (mutations/bp) was $1.4 \%$ with a range of 2-9 mutations per clone, a mutation frequency lower, however, than that observed in IgM (3.2\%) and IgG $(5.4 \%) V_{H 6}$ rearrangements of normal individuals. These results suggest that somatic mutation may be initiated in a CD40 ligand-independent pathway before entry of B cells into germinal centers, but fails to achieve the high mutation frequency observed in the presence of germinal centers. (J. Clin. Invest. 1995. 95:1389-1393.) Key words: somatic mutation • immunoglobulin genes • variable regions - immunodeficiency • HyperIgM syndrome
\end{abstract}

\section{Introduction}

B lymphocytes undergo a process of somatic hypermutation after in vivo activation by antigen and $\mathrm{T}$ cells that introduces

Address correspondence to Richard A. Insel, Department of Pediatrics, University of Rochester, 601 Elmwood Avenue, Box 777, Rochester, NY 14642. Phone: 716-275-0414; FAX: 716-271-7512.

Received for publication 13 October 1994 and in revised form 15 December 1994.

1. Abbreviations used in this paper: CD40L, CD40 ligand; CDR, complementarity determining region; FR, framework region; HIGMX-1, Xlinked HyperIgM syndrome; R/S, ratio of replacement mutation to translationally silent mutations; SSCP, single-stranded conformation polymorphism; TD, thymus dependent; $\mathrm{V}$, variable region.

J. Clin. Invest.

(c) The American Society for Clinical Investigation, Inc.

0021-9738/95/03/1389/05 \$2.00

Volume 95, March 1995, 1389-1393 point mutations into the rearranged immunoglobulin variable region $(\mathrm{V})^{\prime}(1-3)$. Mutations that increase affinity of the surface $\mathrm{Ig}$ of the B cell are then selected into the repertoire by antigen and $\mathrm{T}$ cells. The signals that activate this mutation process are unknown. Somatic mutation of $\operatorname{Ig} \mathrm{V}$ regions is most prominent in B cells in germinal centers of lymphoid tissue (47 ). It is unclear, however, whether the mutation process is activated initially in germinal centers or begins with B cell activation in extrafollicular sites in lymphoid organs and then increases to a high rate when these activated $\mathrm{B}$ cells enter into germinal centers. Suggestive of the former possibility is the finding that when the sequences of $\mathrm{Ig} \mathrm{V}$ regions of $\mathrm{B}$ cells in extrafollicular sites and germinal centers are compared, somatic mutation is found only in B cells isolated from germinal centers $(8,9)$. Also, somatic mutation of $\mathrm{V}$ genes is not invariably observed in B cells that initially populate germinal centers early after immunization $(9,10)$. Alternatively, some investigators have suggested that mutations are introduced after immunization into rearranged $\mathrm{Ig} \mathrm{V}$ region genes before the time of development of germinal centers $(6,11)$.

Germinal center formation fails to occur in mice in the absence of normal CD40-CD40 ligand (CD40L) interactions as found in CD40 (12,13) and CD40L (14) gene-targeted deficient mice. The CD40 and CD40L gene-deficient mice fail to generate IgG antibody responses to thymus-dependent (TD) antigens and memory B cells, but do develop normal levels of serum IgM, normal IgM, and IgG antibody responses to thymusindependent antigens, and IgM antibody responses to some, but not all, TD antigens (12-14). Affinity maturation of antibody or generation of somatic mutation in rearranged Ig $\mathrm{V}$ regions in these gene-deficient mice has not been described.

The human X-linked HyperIgM syndrome (HIGMX-1) is associated with abnormal CD40L function (15-18). Affected boys with this disorder suffer from recurrent pyogenic infections, autoimmune diseases, and lymphoproliferative disorders. They have normal to elevated levels of IgM, but decreased to absent levels of IgG, IgA, and IgE (19). Circulating B cells in patients with HIGMX-1 are normal in number but are usually surface IgM positive with absence of cell surface IgG or IgA. Patients with HIGMX-1 fail to generate germinal centers, IgG antibody, and normal secondary antibody responses, but they do generate IgM antibody, even after immunization with TD antigens $(19,20)$. CD40-CD40L interactions are important in $\mathrm{B}$ cell proliferation, $\mathrm{B}$ cell isotype switching with costimulation with cytokines, and, possibly, in prevention of B cell apoptosis (15-18, 21, 22). Signaling of B cells through CD40 interactions has been suggested to occur in extrafollicular sites in 
lymphoid organs in the initial activation of B cells as well as in germinal centers in the selection of memory $B$ cells $(17,18$, 23,24 ) and, therefore, the immunologic defects in these patients can be explained by an abnormality of CD40 signaling at these sites.

It is not known whether the immunoglobulin or IgM antibody of patients with HIGMX-1 undergoes somatic mutation and shows affinity maturation. We have here determined whether somatic mutation occurs in Ig gene rearrangements of the nonpolymorphic human $\mathrm{V}_{\mathrm{H} 6}$ gene in patients with HIGMX1. The results demonstrate that somatic hypermutation of Ig gene rearrangements can occur in these patients. Some of the mutations had characteristics suggestive of having been antigen selected. Both the frequency of mutated Ig gene rearrangements and the mutation frequency were lower than that observed in the normal host. The findings provide insight into regulation of the initiation of the mutation process and may explain the high incidence of autoimmune disease in these patients.

\section{Methods}

Source of cells. Peripheral blood mononuclear cells were isolated from three patients (HIGMX-1-1, -2, and -3) with the X-linked HyperIgM syndrome. $\mathrm{T}$ cells from these patients were activated and evaluated for expression of functional CD40L using soluble CD40, as described (25, 26). The CD40L gene defect in these patients was characterized by reverse transcriptase-PCR, cloning, and sequencing, as described (26).

Cloning and sequencing of $V_{H 6}$ transcripts. Total cellular RNA was isolated from $\sim 10 \times 10^{6}$ frozen peripheral blood mononuclear cells with TRI Reagent (Molecular Research Center Inc., Cincinnati, OH) according to the manufacturer's specifications. Single-stranded cDNA was prepared from 7-10 $\mu \mathrm{g}$ of the isolated RNA with $200 \mathrm{U}$ Moloney murine leukemia virus reverse transcriptase (GIBCO BRL, Gaithersburg, MD) and $2 \mu \mathrm{g}$ of random hexamer primers (Boehringer Mannheim Biochemicals, Indianapolis, IN). The cDNA was amplified by PCR using the following oligonucleotide primers: $\mathrm{V}_{\mathrm{H} 6}-\mathrm{dU}-5^{\prime} \mathrm{CUACUA}-$ CUACUAGAGGTACAGCTGCAGCAGTCAGGT, a sense primer complementary to the 5' VH6 sequence; Cu-dU-5'CAUCAUCAUCAUTCTCACAGGAGACGAGGGGGAA, an antisense primer complementary to the 5 ' region of the human $\mathrm{C} \mu$ gene segment; and $\mathrm{C} \gamma$-dU-5 'CAUCAUCAUCAUCAGGGGGAAGACC/GGATGGGCCCTT, an antisense primer complementary to the $5^{\prime}$ region of the human $\mathrm{C} \gamma$ gene segment. All primers contained deoxyuracil residues to facilitate directional cloning of the amplified product into the plasmid vector pAMP (see below).

The PCR reaction conditions included $200 \mu \mathrm{M}$ dNTP and 2.5 units of Taq polymerase (Promega Corp., Madison, WI) in a 50- $\mu$ l reaction volume. The thermal cycling profile consisted of an initial denaturing step for $2 \mathrm{~min}$ at $94^{\circ} \mathrm{C}$, and then 35 cycles with an annealing temperature of $55^{\circ} \mathrm{C}$ for $45 \mathrm{~s}$, elongation at $72^{\circ} \mathrm{C}$ for $2 \mathrm{~min}$, and denaturation at $94^{\circ} \mathrm{C}$ for $45 \mathrm{~s}$. This was followed by a final annealing step at $55^{\circ} \mathrm{C}$ for $2 \mathrm{~min}$ and elongation at $72^{\circ} \mathrm{C}$ for $8 \mathrm{~min}$.

Amplified DNA products were isolated on a $1.2 \%$ SeaPlaque low melt agarose gel, and the desired band ( $\sim 350-400$ bp in length) was excised from the gel and directly cloned into the plasmid vector pAMP (GIBCO BRL) by treatment with uracil DNA glycosylase (GIBCO BRL), and transformed into competent XL1-Blue bacteria. Single clones were randomly picked and grown in LB plus ampicillin overnight at $37^{\circ} \mathrm{C}$. Plasmid DNA was isolated using the Wizard Miniprep kit (Promega Corp.). $\mathrm{V}_{\mathrm{H} 6}$ inserts were sequenced bidirectionally by the University of Rochester Core Nucleic Acid laboratory on an Applied Biosystems (Foster City, CA) 370A automated DNA sequencer.

Analysis of single-stranded conformation polymorphism (SSCP). To identify mutated $\mathrm{V}_{\mathrm{H} 6}$ transcripts, single recombinant clones were selected, grown overnight, and then lysed by boiling for $10 \mathrm{~min} .1 \mu \mathrm{l}$ of this lysate was amplified with the $\mathrm{V}_{\mathrm{H} 6}$ - $\mathrm{dU}$ sense primer above and a
$\mathrm{V}_{\mathrm{H} 6}$ specific antisense primer-5'TGTGTCGGATCCACAGTAATACACAGCCGTGTC, complementary to the framework region (FR)3 of VH6, in a 10- $\mu \mathrm{l}$ reaction containing $70 \mu \mathrm{M}$ dNTPs, $0.1 \mu 13,000 \mathrm{Ci} /$ mmol ${ }^{32} \mathrm{P}$ dCTP (Amersham Corp., Arlington Heights, Il), and $1 \mathrm{U}$ of Taq polymerase (Promega Corp.) under the cycling conditions described above. $2 \mu \mathrm{l}$ of the labeled PCR product was diluted 1:50 with $0.1 \%$ SDS, $10 \mathrm{mM}$ EDTA, and $2 \mu \mathrm{l}$ of this was mixed with sequencing stop buffer (United States Biochemicals Corp., Cleveland, OH). Samples were heated at $97^{\circ} \mathrm{C}$ for $3 \mathrm{~min}$, quenched on ice, and electrophoresed at $10 \mathrm{~W}$ constant power through $5 \%$ nondenaturing polyacrylamide gels containing $10 \%$ glycerol for $16-24 \mathrm{~h}$ at room temperature (27). Gels were dried and exposed to autoradiographs (X-OMAT; Eastman Kodak Co., Rochester, NY) for $24 \mathrm{~h}$ at $-70^{\circ} \mathrm{C}$. Clones that exhibited electrophoresis patterns different from the germline pattern were then sequenced as described above.

Determination of PCR fidelity. A clone containing a previously sequenced germline $\mathrm{V}_{\mathrm{H} 6}$ sequence was reamplified with sense and antisense $\mathrm{dU}$ primers and recloned into pAMP as described above. 10 clones were randomly picked and sequenced bidirectionally to identify any base differences.

\section{Results and Discussion}

Peripheral blood lymphocytes of three patients with HIGMX1 were studied. Activated T cells of all three patients failed to express a functional CD40L as assessed by staining with soluble CD40 $(25,26)$. The defects in the CD40L gene in the three patients are shown in Table I. As a result of the mutation, the CD40L mRNA in patient 1 encodes for an altered polypeptide which terminates prematurely (26). Patient 2 had a single point mutation that alters $\mathrm{Gly}_{257}$ to Ser, and patient 3 had an inframe 6-bp deletion that causes the deletion of $\mathrm{Glu}_{142}$ and $\mathrm{Lys}_{143}$ (Fuleihan, R., N. Ramesh, F. S. Rosen, and R. Geha, unpublished observations).

Somatic mutation of $\mathrm{V}_{\mathrm{H} 6}$ gene rearrangements was studied because the $\mathrm{V}_{\mathrm{H} 6}$ gene has been demonstrated to be nonpolymorphic in humans $(28,29) . \mathrm{V}_{\mathrm{H}}$ rearrangements to $\operatorname{IgM}$ and IgG were analyzed because we, as well as others, have demonstrated mutations universally in IgG $(30,31)$ and commonly in IgM $\mathrm{V}_{\mathrm{H} 6}$ rearrangements $(32,33)$.

Both IgM and IgG-productive $\mathrm{V}_{\mathrm{H} 6}$ rearrangements were cloned from peripheral blood lymphocytes from all three patients. The frequency of unique $\mathrm{V}_{\mathrm{H} 6}$ IgG rearrangements was markedly lower than in the normal host, who expressed a diverse $\mathrm{V}_{\mathrm{H} 6}$ IgG repertoire $(30,31)$. Based on analysis of the DJ region of these rearrangements, we isolated only 6 unique $\mathrm{V}_{\mathrm{H} 6}$ IgG rearrangements from sequencing 17 clones from these patients because of the isolation of multiple duplicate clones. Only one unique $\mathrm{V}_{\mathrm{H} 6}$ IgG rearrangement was isolated from patient 2 , which was mutated (see below), as well as from patient 3 from sequencing four and five clones, respectively, from these patients. In contrast, a single normal individual can express over nine unique $\mathrm{V}_{\mathrm{H} 6}$ IgG rearrangements and isolation of duplicate clones from normal individuals is much rarer (only 6 duplicates in 23 sequenced clones) (30). It is unknown whether these IgG $\mathrm{V}_{\mathrm{H} 6}$ rearrangements arose from $B$ cells that had undergone deletional isotype switching to IgG or arose from B cells with long-processed $\mathrm{V}_{\mathrm{H} 6}$ transcripts without having undergone deletional switching. EBV-transformed cell lines have been established from patients with HIGMX-1 that express the same $\mathrm{V}$ gene with both IgM and IgG isotypes without having undergone deletional switching (34). In contrast to the $\mathrm{V}_{\mathrm{H} 6}$ IgG rearrangements, unique $\mathrm{V}_{\mathrm{H} 6}$ IgM rearrangements were commonly 
Table I. Family History and CD40 Ligand Protein and mRNA Expression and Gene Defect in HyperIgM Patients

\begin{tabular}{lcccccc}
\hline & $\begin{array}{c}\text { Family } \\
\text { history }\end{array}$ & $\begin{array}{c}\text { CD40L } \\
\text { expression }\end{array}$ & $\begin{array}{c}\text { CD40L } \\
\text { mRNA }\end{array}$ & Mutation & Reference \\
\hline HIGMX-1-1 & + & - & + & $\mathrm{C} \rightarrow$ A transversion at nt $590^{*}$ followed by deletion of a C & 25,26 \\
HIGMX-1-2 & + & - & + & $\mathrm{G} \rightarrow$ A transition at nt $769 *$ changing Gly $_{257} \rightarrow$ Ser & Unpublished observation \\
HIGMX-1-3 & + & - & + & 6 bp in-frame deletion nt $424-429 *$ & Unpublished observation
\end{tabular}

* Numbering starts from the A of the initiator (ATG) codon.

expressed in these patients with no duplicates in 22 clones sequenced randomly from these three patients. Among these 22 IgM and 17 IgG randomly selected clones, there was one IgM and one IgG clone that was mutated, as detailed below. To more efficiently screen for mutated clones among the IgM rearrangements, we analyzed for SSCP, which is capable of detecting single point mutations. Clones with altered SSCP mobility on nondenaturing gels were then sequenced.

Although the majority of both IgM and IgG $\mathrm{V}_{\mathrm{H} 6}$ rearrangements were in germline form, there were a total of 7 of 102 ( 22 randomly selected and 80 screened by SSCP) IgM and 1 of $6 \mathrm{IgG} \mathrm{V}_{\mathrm{H} 6}$ rearrangements that had somatic mutations in $\mathrm{V}_{\mathrm{H} 6}$. Patient 1 and patient 2 had 7 of $66 \mathrm{IgM}$ and 1 of $5 \mathrm{IgG}$ $\mathrm{V}_{\mathrm{H} 6}$ rearrangements that were mutated. None of 36 IgM or the single IgG $\mathrm{V}_{\mathrm{H} 6}$ rearrangement(s) of patient 3 was mutated. The isolation of germline $\mathrm{V}_{\mathrm{H} 6}$ IgG sequences contrasts with the finding of mutation in all of the $\mathrm{V}_{\mathrm{H} 6}$ IgG rearrangements isolated from normal individuals $(30,31)$, and suggests these $\mathrm{V}$ genes may arise from $B$ cells that had not undergone deletional isotype switching, as described above. The finding that most HIGMX1 IgM rearrangements were also in germline form, also contrasts with the $\mathrm{V}_{\mathrm{H} 6}$ IgM rearrangements of healthy individuals, which are mutated in at least two-thirds of $\mathrm{V}_{\mathrm{H} 6}$ rearrangements when rearrangements are cloned from RNA of lymphocytes $(32,33)$. Mutated V genes expressed with IgM may arise from B cells that have been activated in vivo. When $\mathrm{V}$ gene sequences of human surface IgM+IgD+ and surface IgM+IgD- B cells are compared, the $\mathrm{V}$ genes of the former $\mathrm{B}$ cell subset, which probably represent "naive"' B cells, are invariably in germline form while those of the latter subset, which may represent previously activated B cells, are usually mutated (35). Characterization of $\mathrm{V}$ genes by use of RNA, as performed here, will skew the results to analysis of $\mathrm{V}$ genes of activated $\mathrm{B}$ cells because of the higher levels of Ig mRNA in activated than in resting $B$ cells.

The number of mutations per mutated rearrangement ranged from two to nine with a mean of four mutations for the 281 nucleotide bases sequenced between the primers in the $\mathrm{V}_{\mathrm{H} 6}$ gene, or a mutation frequency (mutations/bp) of $1.4 \%$ (Fig. 1 ). The highest frequency was observed in the single-mutated IgG clone $(3.2 \%)$. This mutation frequency was less than the $3.2 \%$ and $5.4 \%$ mutation frequency observed in $\mathrm{V}_{\mathrm{H} 6}$ rearrangements of the IgM and IgG isotype of normal individuals (30-33). This frequency, however, was 26-fold greater than the frequency of $\mathrm{V}_{\mathrm{H} 6}$ background mutations from PCR amplification error, which was quantitated at $5.4 \times 10^{-4}$ errors/bp ( 1 error per $1,838 \mathrm{bp}$ ), representing about 1 error per 6-7 clones of $281 \mathrm{bp}$. More than one PCR-induced error per clone was not observed.

The distribution and characteristics of the mutations from these clones are shown (Fig. 1), and tabulated (Table II). 17 mutations were in the complementarity determining region (CDR) and 15 in the FR. There were 24 replacement and 8 translationally silent mutations, which gave a replacement to silent mutation ( $R / S$ ) ratio of 3.0. The $C D R 1$ of $V_{H 6}$ was mutated in two rearrangements (HIGMX-1-1-5M, HIGMX1-2$3 G$ ) with an $R / S$ ratio of 6:0. Overall, the CDR had an R/S of 3.2 and the FR had a R/S of 2.8. The R/S in CDR1 exceeded the $R / S$ ratio in CDR1 that would be expected based on the germline sequence, as shown (Table II) $(31,36)$. In these rearrangements, the $\mathrm{R} / \mathrm{S}$ for the total CDR was identical to and the $R / S$ in CDR 1 exceeded that observed in mutations of $V_{H 6}$ rearrangements of normal individuals (31). The $R / S$ of the mutations in CDR1 (R/S of 6:0) and in CDR2 of the one clone, HIGMX1-1-16M, (R/S of 3:0), are suggestive of their arising by antigenic selection.

The findings suggest that a low frequency of somatic mutation occurs in some Ig rearrangements in the absence of normal CD40L-CD40 interactions and germinal center formation in HIGMX-1. Leakiness of the gene defect in these patients does not appear to account for these findings. First, we did not detect expression of CD40L with soluble CD40 on activated PBL of these patients. Second, there was an extreme rarity of unique IgG rearrangements detected, and when detected, they were usually in germline form. This finding suggests that these rearrangements may have been derived from B cells that had not undergone deletional isotype switching. Mutated clones were usually of the IgM isotype, representing over $10 \%$ of the IgM rearrangements in patients 1 and 2. Mutation is, therefore, occurring in the absence of leakiness for isotype switching, a process that requires CD40L-CD40 signaling. It has been shown recently that expression of the wild-type CD40L, by only a small population of $\mathrm{T}$ cells in carriers of HIGMX-1, is sufficient to maintain normal isotype switching to IgG and antibody responses (37).

Both the frequency of $\mathrm{V}_{\mathrm{H} 6}$ rearrangements with mutation and the mutation frequency when it occurred was lower, however, than in the normal host. In part, the mutation frequency could be lower in HIGMX-1 than in normal individuals because of the failure to generate long-term memory B cells in this syndrome $(19,20)$. Milstein and colleagues suggest that the somatic mutation process can recur multiple times in memory B cells (38) and, thus, could add to the frequency of mutations observed in $\mathrm{V}$ genes in normal individuals.

It has been debated whether somatic mutation initiates only in germinal centers or begins outside follicles before germinal center formation with activated B cells with a low frequency of mutation then migrating to form germinal centers and undergoing increased mutation $(8,11)$. The somatic mutations observed in the $\mathrm{V}$ genes of these patients are possibly induced in 
$\boldsymbol{\lambda .}$
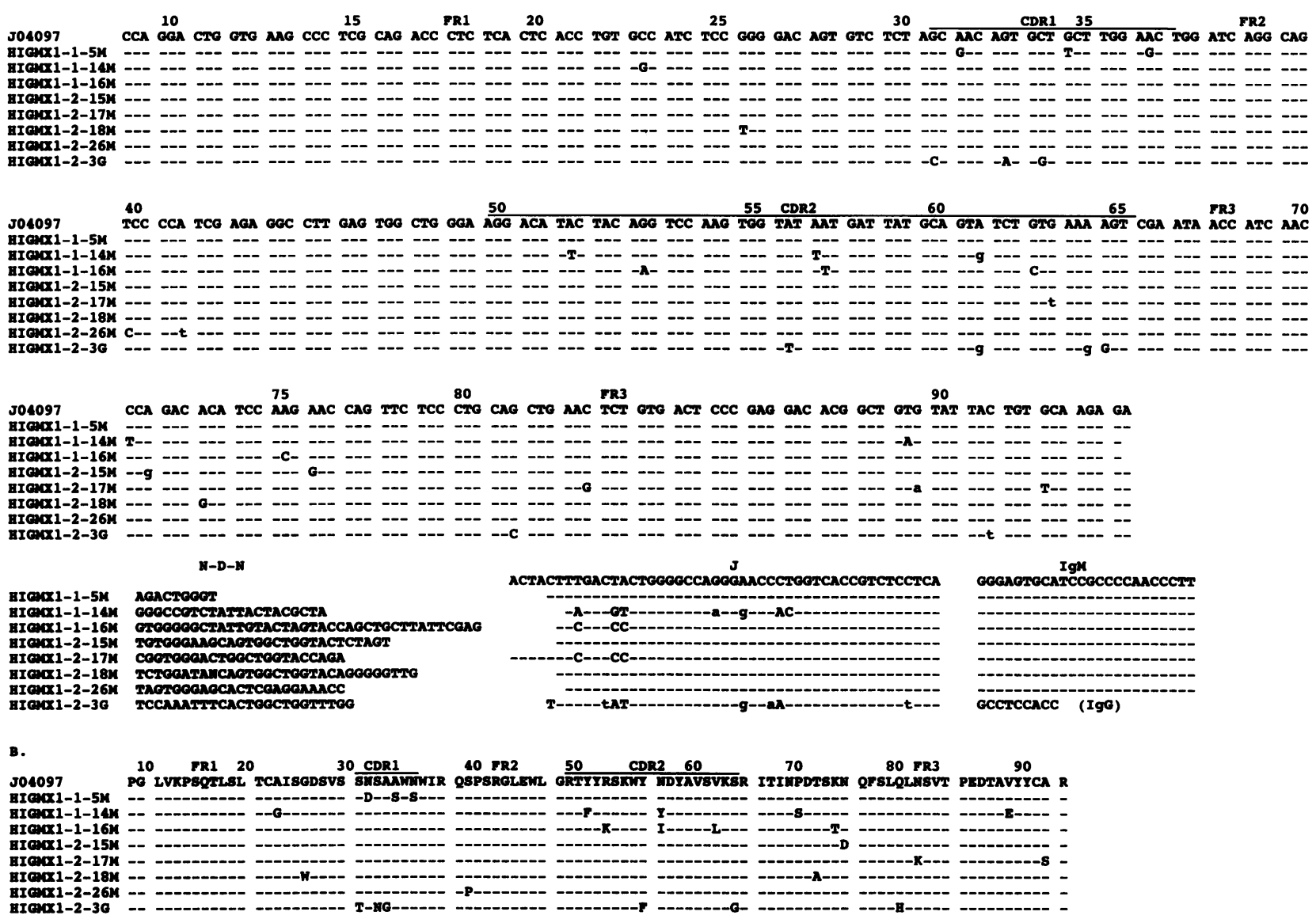

Figure I. Nucleotide $(A)$ and translated $(B)$ sequences of mutated $\mathrm{V}_{\mathrm{H} 6}$ rearrangements from peripheral blood lymphocytes of patients with the HyperIgM syndrome. Clones were derived from patient 1 (HIGMXI-I) and patient 2 (HIGMXI-2). All clones were IgM rearrangements except $H I G M X I-2-3 G$, which was an IgG rearrangement. Capital and lower case letters represent replacement and translationally silent mutations, respectively. Dashes indicate positions with sequence identity with the germline. Sequences not attributed to $\mathrm{V}_{\mathrm{H} 6}$ or $\mathrm{J}_{\mathrm{H}}$ have been assigned as $\mathrm{N}$-additions or to the $\mathrm{D}$ region. Nucleotide sequences are compared to the published $\mathrm{V}_{\mathrm{H} 6}$ genomic sequence $\mathrm{J} 04097$ (42). The sequences start 3' of the 5' $\mathrm{V}_{\mathrm{H} 6}$ primer. These sequences are available from EMBL/GenBank under accession numbers U13195-U13202.

extrafollicular locations through a CD40-independent pathway that induces a low level of somatic mutation. Based on recent studies of in vivo injection of mice with a soluble CD40 fusion protein, Gray and colleagues have suggested that there exists a TD, CD40L-independent pathway that leads to IgM antibody responses (39). Such a pathway could explain IgM antibody responses to TD antigens in the X-linked HyperIgM syndrome $(19,20)$ and to some TD antigens in CD40 and CD40L gene knockout mice $(12,14)$. Although memory $B$ cells are not generated in the absence of normal CD40L function (12-14, $20,39,40$ ), this CD40L independent pathway may represent a minor pathway in the normal host that is capable of activating proliferation of surface IgM expressing B cells. In the presence of normal CD40L function, these activated cells would immediately traffic to germinal centers and undergo more extensive mutation and would, therefore, not be detected. The results here suggest this pathway is capable of initiating somatic mutation. The relatively lower frequency of mutation compared to $\mathrm{V}_{\mathrm{H} 6}$

Table II. Replacement and Silent Mutations in Framework Regions and Complementarity Determining Regions of Eight $V_{H 6}$ Rearrangements in the $X$-Linked HyperIgM Syndrome

\begin{tabular}{|c|c|c|c|c|c|c|c|c|}
\hline & FR1 & CDR1 & FR2 & CDR2 & FR3 & Total FR & Total CDR & Total \\
\hline $\mathrm{R}$ & 2 & 6 & 1 & 7 & 8 & 11 & 13 & 24 \\
\hline$S$ & 0 & 0 & 1 & 4 & 3 & 4 & 4 & 8 \\
\hline Total & 2 & 6 & 2 & 11 & 11 & 15 & 17 & 32 \\
\hline Observed R/S & $>2$ & $>6$ & 1.0 & 1.8 & 2.7 & 2.8 & 3.2 & 3.0 \\
\hline Expected R/S* & 2.4 & 5.1 & 2.9 & 3.8 & 3.0 & 2.8 & 4.1 & 3.0 \\
\hline
\end{tabular}

* Expected based on germline $\mathrm{V}_{\mathrm{H} 6}$ gene sequence $(31,36) . \mathrm{R}$, replacement mutation; $\mathrm{S}$, silent mutation. 
rearrangement of normal individuals suggests that a germinal center environment is required for a high rate of mutation.

Generation of mutated antibodies in the absence of germinal center formation in patients with HIGMX-1 may not allow deletion of B cells that express self-reactive antibodies (41). The ability to generate mutated immunoglobulins in the absence of germinal center formation may promote the development of autoantibodies and could explain the high frequency of autoimmune disease that occurs in patients with HIGMX-1 (19).

\section{Acknowledgments}

The authors would like to thank Jonathan Gitlin, M.D. and Ralph Shapiro, M.D. for providing blood samples.

This work was supported in part by the National Institutes of Health grants AI37123, AI31136, and AI35714.

\section{References}

1. Weigert, M., I. M. Cesari, S. J. Yonkovich, and M. Cohn. 1970. Variability in the lambda light chain sequences of mouse antibody. Nature (Lond.). 228:1045-1047.

2. Kocks, C., and K. Rajewsky. 1989. Stable expression and somatic hypermutation of antibody $\mathrm{V}$ regions in B cell developmental pathways. Annu. Rev. Immunol. 7:537-559.

3. French, D. L., R. Laskov, and M. D. Scharff. 1989. The role of somatic hypermutation in the generation of antibody diversity. Science (Wash. DC). 244:1152-1157.

4. Jacob, J., G. Kelsoe, K. Rajewsky, and U. Weiss. 1991. Intraclonal generation of antibody mutants in germinal centres. Nature (Lond.). 354:389-392.

5. Berek, C., A. Berger, and M. Apel. 1991. Maturation of the immune response in germinal centers. Cell. 67:1121-1129.

6. Berek, C. 1992. The development of B cells and the B-cell repertoire in the microenvironment of the germinal center. Immunol. Rev. 126:5-19.

7. MacLennan, I. C. M. 1994. Germinal centers. Annu. Rev. Immunol. 12:117139.

8. Jacob, J., and G. Kelsoe. 1992. In situ studies of the primary immune response to (4-hydroxy-3-nitrophenyl) acetyl. II. A common clonal origin for PALS-associated foci and germinal centers. J. Exp. Med. 176:679-687.

9. Jacob, J., J. Przylepa, C. Miller, and G. Kelsoe. 1993. In situ studies of the primary immune response to (4-hydroxy-3-nitrophenyl) acetyl. III. The kinetics of $\mathrm{V}$ region mutation and selection in germinal center B cells. J. Exp. Med. 178:1293-1307.

10. McHeyzer-Williams, M. G., M. J. McLean, P. A. Lalor, and G. J. V. Nossal. 1993. Antigen-driven B cell differentiation in vivo. J. Exp. Med. 178:295307.

11. Leanderson, T., E. Kallberg, and D. Gray. 1992. Expansion, selection and mutation of antigen-specific B cells in germinal centers. Immunol. Rev. 126:4761.

12. Kawabe, T., T. Naka, K. Yoshida, T. Tanaka, H. Fujiwara, S. Suematsu, N. Yoshida, T. Kishimoto, and H. Kikutani. 1994. The immune responses in CD40-deficient mice: impaired immunoglobulin class switching and germinal center formation. Immunity. 1:167-178.

13. Castigli, E., F. Alt, L. Davidson, A. Bottaro, E. Mizoguchi, A. K. Bhan, and R. S. Geha. 1994. CD40 deficient mice generated by RAG-2 deficient blastocyst complementation. Proc. Natl. Acad. Sci. USA. 91:12135-12139.

14. Xu, J., T. M. Foy, J. D. Laman, E. A. Elliott, J. J. Dunn, T. J. Waldschmidt, J. Elsemore, R. J. Noelle, and R. A. Flavell. 1994. Mice deficient for the CD40 ligand. Immunity. 1:423-431.

15. Ramesh, N., R. Fuleihan, and R. Geha. 1994. Molecular pathology of "Xlinked immunoglobulin deficiency with normal or elevated IgM (HIGMX-1)." Immunol. Rev. 138:87-104.

16. Kroczek, R. A., D. Graf, D. Brugnoni, S. Giliani, U. Korthauer, G. Senger, H. W. Mages, A. Villa, and L. D. Notarangelo. 1994. Defective expression of CD40 ligand on T cells causes "X-linked immunodeficiency with Hyper-IgM (HIGM1)." Immunol. Rev. 138:39-59.

17. Hollenbaugh, D., H. D. Ochs, R. J. Noelle, J. A. Ledbetter, and A. Aruffo. 1994. The role of CD40 and its ligand in the regulation of the immune response. Immunol. Rev. 138:24-37.

18. Callard, R. E., R. J. Armitage, W. C. Fanslow, and M. K. Spriggs. 1993. CD40 ligand and its role in X-linked hyper-IgM syndrome. Immunol. Today. 14:559-564.

19. Notarangelo, L. D., M. Duse, and A. G. Ugazio. 1992. Immunodeficiency with hyper-IgM (HIM). Immunodefic. Rev. 3:101-122.
20. Nonoyama, S., D. Hollenbaugh, A. Aruffo, J. A. Ledbetter, and H. D. Ochs. 1993. B cell activation via CD40 is required for specific antibody production by antigen-stimulated human B cells. J. Exp. Med. 178:1097-1102.

21. Banchereau, J., F. Bazan, D. Blanchard, F. Briere, J. P. Galizzi, C. van Kooten, Y. J. Liu, F. Rousset, and S. Saeland. 1994. The CD40 antigen and its ligand. Annu. Rev. Immunol. 12:881-922.

22. Tsubata, T., J. Wu, and T. Honjo. 1993. B-cell apoptosis induced by antigen receptor crosslinking is blocked by a T-cell signal through CD40. Nature (Lond.). 364:645-648.

23. Van den Eertwegh, A. J. M., R. J. Noelle, M. Roy, D. M. Shepherd, A. Aruffo, J. A. Ledbetter, W. J. A. Boersma, and E. Claassen. 1993. In vivo CD40gp39 interactions are essential for thymus-dependent humor immunity. I. In vivo expression of CD40 ligand, cytokines, and antibody production delineates sites of cognate T-B cell interactions. J. Exp. Med. 178:1555-1565.

24. Lederman, S., M. J. Yellin, G. Inghirami, J. J. Lee, D. M. Knowles, and L. Chess. 1992. Molecular interactions mediating T-B lymphocyte collaboration in human lymphoid follicles. Roles of $T$ cell-B-cell activating molecule (5c8 antigen) and CD40 in contact-dependent help. J. Immunol. 149:3817-3826.

25. Fuleihan, R., N. Ramesh, R. Loh, H. Jabara, F. S. Rosen, T. Chatila, S. M. Fu, I. Stamenkovic, and R. S. Geha. 1993. Defective expression of the CD40 ligand in X chromosome-linked immunoglobulin deficiency with normal or elevated IgM. Proc. Natl. Acad. Sci. USA. 90:2170-2173.

26. Ramesh, N., R. Fuleihan, V. Ramesh, S. Lederman, M. J. Yellin, S. Sharma, L. Chess, F. S. Rosen, and R. S. Geha. 1993. Deletions in the ligand for CD40 in X-linked immunoglobulin deficiency with normal or elevated IgM (HIGMX-1). Int. Immunol. 5:769-773.

27. Dean, M., and B. Gerrard. 1991. Helpful hints for the detection of singlestranded conformation polymorphisms. Biotechniques. 10:332-333.

28. Sanz, I., P. Kelly, C. Williams, S. Scholl, P. Tucker, and J. D. Capra. 1989. The smaller human $\mathrm{V}_{\mathrm{H}}$ gene families display remarkably little polymorphism. Eur. Mol. Biol. Organ. J. 8:3741-3748.

29. Willems van Dijk, K., H. W. Schroeder, Jr., R. M. Perlmutter, and E. C. B. Milner. 1989. Heterogeneity in the human Ig VH locus. J. Immunol. 142:2547-2554.

30. Varade, W. S., E. Marin, A. M. Kittelberger, and R. A. Insel. 1993. Use of the most $\mathrm{J}_{\mathrm{H}}$-proximal human immunoglobulin heavy chain variable region gene, $\mathrm{V}_{\mathrm{H} 6}$, in the expressed immune repertoire. J. Immunol. 150:4985-4995.

31. Insel, R. A., and W. S. Varade. 1994. Bias in somatic hypermutation of human $\mathrm{V}_{\mathrm{H}}$ genes. Int. Immunol. 6:1437-1443.

32. Insel, R. A., W. S. Varade, and E. Marin. 1994. Human splenic IgM immunoglobulin transcripts are mutated at high frequency. Mol. Immunol. 31:383-392

33. van Es, J. H., F. H. J. Gmelig, and T. Logtenberg. 1992. High frequency of somatically mutated IgM molecules in the human adult blood B cell repertoire. Eur. J. Immunol. 22:2761-2764.

34. Akahori, Y., Y. Kurosawa, Y. Kamachi, S. Torii, and H. Matsuoka. 1990. Presence of immunoglobulin (Ig) M and IgG double isotype-bearing cells and defect of switch recombination in Hyper IgM immunodeficiency. J. Clin. Invest. 85:1722-1727.

35. Klein, U., R. Kuppers, and K. Rajewsky. 1993. Human IgM+IgD+ B cells, the major B cell subset in the peripheral blood, express $V_{\kappa}$ genes with no or little somatic mutation throughout life. Eur. J. Immunol. 23:3272-3277.

36. Chang, B., and P. Casali. 1994. The CDR1 sequences of a major proportion of human germline $I g \mathrm{~V}_{\mathrm{H}}$ genes are inherently susceptible to amino acid replacement. Immunol. Today. 15:367-373.

37. Hollenbaugh, D., L. H. Wu, H. D. Ochs, S. Nonoyama, L. S. Grosmaire, J. A. Ledbetter, R. J. Noelle, H. Hill, and A. Aruffo. 1994. The random inactivation of the $\mathrm{x}$ chromosome carrying the defective gene responsible for $\mathrm{x}$-linked hyper IgM syndrome (X-HIM) in female carriers of HIGM1. J. Clin. Invest. 94:616622

38. Rada, C., S. K. Gupta, E. Gherardi, and C. Milstein. 1991. Mutation and selection during the secondary response to 2-phenyloxazolone. Proc. Natl. Acad. Sci. USA. 88:5508-5512.

39. Gray, D., P. Dullforce, and S. Jainandunsing. 1994. Memory B cell development but not germinal center is impaired by in vivo blockade of CD40-CD40 ligand interaction. J. Exp. Med. 180:141-155.

40. Foy, T. M., J. D. Laman, J. A. Ledbetter, A. Aruffo, E. Claassen, and R. J. Noelle. 1994. gp39-CD40 interactions are essential for germinal center formation and the development of B cell memory. J. Exp. Med. 180:157-163.

41. Nossal, G. J. V. 1994. Differentiation of the secondary B-lymphocyte repertoire: the germinal center reaction. Immunol. Rev. 137:173-183.

42. Schroeder, H. W., M. A. Walter, M. H. Ho f ker, A. Ebers, K. Willems van Dijk, L. C. Liao, D. W. Cox, E. C. B. Milner, and R. M. Perlmutter. 1988. Physical linkage of a human immunoglobulin heavy chain variable region gene segments to diversity and joining segments. Proc. Natl. Acad. Sci. USA. 85:81968200 . 